\title{
Physico-chemical characterization and partial sequence of a lectin from Canavalia bonariensis Lindl seeds
}

\author{
Mayara Silva*, Suzete Silva, Kyria Nascimento, Celso Nagano, Benildo Cavada \\ From 5th Congress of the Brazilian Biotechnology Society (SBBIOTEC) \\ Florianópolis, Brazil. 10-14 November 2013
}

Lectins are (glycol) proteins that bind specifically and reversibly to carbohydrates. These proteins, in particular those from plant, are important tools in glycobiochemistry and glycobiology. Canavalia bonariensis Lindl is a species of Leguminosae family, Papilionoideae subfamily, tribe Phaseoleae, subtribe Diocleinae, native of the southern region of the country. The objective of this work was to purify a lectin from $C$. bonariensis $(\mathrm{CaBo})$ seeds through affinity chromatographic. The process of purification of CaBo (Canavalia bonariensis Lectin) was monitored by SDS-PAGE and hemagglutinating activity and showed that the purified lectin is characterized by an electrophoretic profile consists of a higher band with approximately 26 $\mathrm{kDa}$, and two bottom bands with apparent molecular mass of 14 and $12 \mathrm{kDa}$. The analysis by mass spectrometry indicated that $\mathrm{CaBo}$ has a chain with molecular mass of $25,512 \mathrm{kDa}$ and and two subunits ( $\beta$ and $\gamma$ chains) with molecular mass of $12,999 \mathrm{Da}$ and $12,537 \mathrm{Da}$, respectively. $\mathrm{CaBo}$ also had its primary sequence partially determined by tandem mass spectrometry, obtaining $61 \%$ of the total sequence of the protein. CaBo was tested for the thermostability of their hemagglutinating activity after incubation for one hour at different temperatures $\left(40^{\circ}\right.$ to $\left.80^{\circ} \mathrm{C}\right)$, losing activity only at $80^{\circ} \mathrm{C}$ after one hour. Regarding its stability at different $\mathrm{pH}$ (4.0 to 10.0), CaBo was stable in a $\mathrm{pH}$ range between 7.0 and 9.0. The CaBo activity was also affected after serial dilution in the presence of the chelating agent EDTA and it was recovered significantly after addition of $\mathrm{CaCl}_{2}$ and $\mathrm{MnCl}_{2} 0,005 \mathrm{~mol} / \mathrm{L}$, proving to be dependent of divalent metal cations.

Universidade Federal do Ceará, Fortaleza, CE, Brazil
Published: 1 October 2014

doi:10.1186/1753-6561-8-S4-P227

Cite this article as: Silva et al:: Physico-chemical characterization and partial sequence of a lectin from Canavalia bonariensis Lindl seeds. BMC Proceedings 2014 8(Suppl 4):P227.
Submit your next manuscript to BioMed Central and take full advantage of:

- Convenient online submission

- Thorough peer review

- No space constraints or color figure charges

- Immediate publication on acceptance

- Inclusion in PubMed, CAS, Scopus and Google Scholar

- Research which is freely available for redistribution
() Biomed Central 